\title{
Association between the IVS4G > T mutation in the TCF7L2 gene and susceptibility to diabetes in cystic fibrosis patients
}

\author{
Daniela Tenório Furgeri ${ }^{1}$, Fernando Augusto de Lima Marson², Antonio Fernando Ribeiro ${ }^{2}$ and \\ Carmen Silvia Bertuzzo $0^{1,3^{*}}$
}

\begin{abstract}
Background: Clinical complications appear to be a decisive factor for the prognosis of patients. Diabetes is an important complication of cystic fibrosis(CF). In our study we evaluated the association between the IVS4G>T mutation in the TCF7L2 gene with the presence of diabetes in patients with CF.

Findings: We evaluated 145 patients with CF in relation to the genotype of the IVS4G>T mutation. For this, the PCR method associated with specific enzyme digestion was used. The genotypes $G / G, G / T$ and $T / T$ were observed to have frequencies of $54(37.2 \%), 78(53.8 \%)$ and 13 (9\%), respectively. There was no association between genotype and the occurrence of diabetes among patients.
\end{abstract}

Conclusions: In our sample, no association was found between the IVS4G>T mutation in the TCF7L2 gene and diabetes.

Keywords: rs12255372, IVS4G > T, TCF7L2, Cystic fibrosis, Diabetes

\section{Findings}

Introduction

Cystic Fibrosis (CF) is a monogenic autosomal recessive disease more common in the Caucasian population. It has the overall prevalence of 1:2500 births [1].

CF occurs due to mutations in the gene CFTR ("Cystic Fibrosis Transmembrane Conductance Regulator") located in the 7q3.1 region, which encodes the CFTR protein. Over 1897 mutations were identified in the CFTR gene [2].

The disease is characterized by a higher viscosity of secretions leading to chronic obstructive pulmonary disease, recurrent respiratory tract infections, pancreatic insufficiency, increased concentration of chloride in sweat and male infertility [1].

The clinical features of CF are characterized by clinical heterogeneity; some individuals have early death, while

\footnotetext{
* Correspondence: bertuzzo@unicamp.br

${ }^{1}$ Department of Medical Genetics, Faculty of Medical Sciences, University of Campinas (UNICAMP), Campinas, SP, Brazil

${ }^{3}$ Universidade Estadual de Campinas (UNICAMP), Rua Tessália Vieira de Camargo, 126, Cidade Universitária, Campinas, SP 13081-970, Brazil Full list of author information is available at the end of the article
}

others survive to adulthood [3]. Clinical complications appear to be a decisive factor for the prognosis of patients. Diabetes is an important complication of CF. Diabetes risk increases with age, affecting about 25\% of adolescents and 40-50\% of adults with CF [4-6]. As CF's patients are now living longer, diabetes has become the most common systemic complication of CF after lung disease. Diabetes is associated with a significantly worse CF prognosis [6,7], although treatment of diabetes improves nutritional status and pulmonary function [8]. Among CF's patients, the prevalence of diabetes is approximately tenfold greater (at about onethird the age) than is seen for type 2 diabetes in the general population $[6,9]$.

Grant et al. [10] reported on the association of a common microsatellite (DG10S478) within intron 3 of the transcription factor 7 -like 2 gene (TCF7L2) with type 2 diabetes in an Icelandic case-control sample and replicated this result in two additional case-control cohorts of white patients. The noncoding single-nucleotide polymorphisms rs12255372 and rs7903146 were in strong linkage disequilibrium with DG10S478 (r2 =0.95 and 
r2 $=0.78$, respectively) and showed similarly robust associations with type 2 diabetes. The authors recommended that these two single-nucleotide polymorphisms be genotyped in all attempts at replication [11].

In our study we evaluated the association of the rs12255372 polymorphism (IVS4G $>\mathrm{T}$ mutation) in TCF7L2 gene with the presence of diabetes in patients with CF.

\section{Results}

This study was approved by the Ethics Committee of the Faculty of Medical Sciences of University of Campinas UNICAMP (\#528/2008).

The study included 145 patients with CF who are monitored by the Pediatric Pulmonology Outpatient Clinic at UNICAMP.

The genotypes G/G, G/T and T/T were observed with frequencies of 54 (37.2\%), $78(53.8 \%)$ and 13 (9\%), respectively. The frequency of $\mathrm{G}$ allele was 0.64 and the $\mathrm{T}$ allele 0.36 .

Of the total patients, 72 patients $(49.7 \%)$ were female and $73(50.3 \%)$ were male, diabetes mellitus was reported in 29 (20.3\%) patients and 114 (79.7\%) had no comorbidity; meconium ileus was diagnosed in 24 patients (16.6\%) and 121 (83.4\%) had no comorbidity.

The ethnicity of the patients was respectively, 136 (93.8\%), 5 (3.4\%) and $4(2.8 \%)$ of Caucasoid, Negroid and mixed race.

For the sample that was screened for the F508del mutation, its frequency was: 37 (25.5\%) F508del/F508del, 60 (41.4\%) with one F508del allele and 48 (33.1\%) patients without the F508del mutation identified.

74 patients (51\%) were aged less or equal than 154 months and 71 patients (49\%) greater than 154 months.

Association between genotype of the IVS4G > T mutation and the development of diabetes and the presence of meconium ileus (Tables 1, 2) was not found. When the variable presence of the F508del mutation was introduced, an association was still not found in our sample (Tables 3,4).

\section{Discussion}

Florez et al. (2006) [11], examined whether the two most strongly associated variants (rs12255372 and rs7903146) predict the progression to diabetes in 3.548 persons with impaired glucose tolerance who were enrolled in the Diabetes Prevention Program, in which lifestyle intervention or treatment with metformin was compared with placebo. The data found showed that the risk alleles in rs7903146 and rs12255372 predict the risk of diabetes prospectively, beyond that conferred by the clinical risk factors.

In 2009, Blackman et al., [6] had already tested whether a family history of type 2 diabetes affected
Table 1 Association IVS4G > T mutation with clinical variables in cystic fibrosis patients followed at the Pediatric Clinic at UNICAMP distribution without the mutations in the CFTR gene

\begin{tabular}{|c|c|c|c|c|}
\hline Sex & Male & Female & Chi-square & p-value \\
\hline $\mathrm{G} / \mathrm{G}$ & 28 (51.9\%) & $26(48.1 \%)$ & 0.144 & 0.93 \\
\hline $\mathrm{G} / \mathrm{T}$ & $39(50 \%)$ & $39(50 \%)$ & & \\
\hline $\mathrm{T} / \mathrm{T}$ & $7(53.8 \%)$ & $6(46.2 \%)$ & & \\
\hline Diabetes & No & Yes & & \\
\hline$\overline{G / G}$ & $39(72.2 \%)$ & $15(27.8 \%)$ & 3.018 & 0.221 \\
\hline $\mathrm{G} / \mathrm{T}$ & $64(84.2 \%)$ & $12(15.8 \%)$ & & \\
\hline $\mathrm{T} / \mathrm{T}$ & $11(84.6 \%)$ & $2(15.4 \%)$ & & \\
\hline Meconium ileus & No & Yes & & \\
\hline $\mathrm{G} / \mathrm{G}$ & $47(87 \%)$ & 7 (13\%) & 1.014 & 0.602 \\
\hline $\mathrm{G} / \mathrm{T}$ & $64(82.1 \%)$ & $14(17.0 \%)$ & & \\
\hline $\mathrm{T} / \mathrm{T}$ & $10(76.9 \%)$ & $3(23.1 \%)$ & & \\
\hline Age & $\leq 154$ months & $>154$ months & & \\
\hline $\mathrm{G} / \mathrm{G}$ & $28(51.9 \%)$ & $26(48.1 \%)$ & 2.141 & 0.343 \\
\hline $\mathrm{G} / \mathrm{T}$ & 37 (47.4\%) & 41 (52.6\%) & & \\
\hline $\mathrm{T} / \mathrm{T}$ & $9(69.2 \%)$ & $4(30.8 \%)$ & & \\
\hline
\end{tabular}

diabetes risk in CF patients in 539 families in the CF Twin and Sibling family-based study. 998 patients were evaluated from the family-based study and 802 unrelated CF patients in an independent case-control study. Family history of type 2 diabetes was shown to increase the risk of diabetes in CF (OR $3.1 ; \mathrm{p}=0.0009)$. A variant in TCF7L2 associated with type 2 diabetes (the $\mathrm{T}$ allele at rs7903146) was associated with diabetes in CF in the family study $(\mathrm{p}=0.004)$ and in the case-control study $(\mathrm{p}=0.02$; combined $\mathrm{p}=0.0002)$. In the family-based

Table 2 Association IVS4G > T mutation in TCF7L2 gene after genotypic groupings with clinical variables in cystic fibrosis patients followed at the Pediatric Clinic at UNICAMP distribution without the mutations in the CFTR gene

\begin{tabular}{lcccc}
\hline Sex & Male & Female & Chi-square & p-value \\
\hline G/G & $26(48.1 \%)$ & $28(51.9 \%)$ & 0.078 & 0.864 \\
G/T and T/T & $46(50.5 \%)$ & $45(49.5 \%)$ & & \\
\hline Diabetes & No & Yes & & \\
\hline G/G & $39(72.2 \%)$ & $15(27.8 \%)$ & 3.017 & 0.091 \\
G/T and T/T & $75(84.3 \%)$ & $14(15.7 \%)$ & & \\
\hline Meconium ileus & No & Yes & & \\
\hline G/G & $47(87 \%)$ & $7(13 \%)$ & 0.802 & 0.489 \\
G/T and T/T & $74(83.4 \%)$ & $7(18.7 \%)$ & & \\
\hline Age & $\leq 154$ months & $>154$ months & & \\
\hline G/G & $28(51.9 \%)$ & $26(48.1 \%)$ & 0.23 & 1 \\
G/T and $T / T$ & $46(50.5 \%)$ & $45(49.5 \%)$ & & \\
\hline
\end{tabular}


Table 3 Association IVS4G > T mutation in TCF7L2 gene, distributed by genotype for the mutation in the CFTR gene delF508 with clinical variables in cystic fibrosis patients followed at the Pediatric Clinic at UNICAMP with the distribution by mutations in the CFTR gene

\begin{tabular}{|c|c|c|c|c|c|}
\hline F508del & Sex & Male & Female & Chi-square & $\mathrm{p}$-value \\
\hline \multirow[t]{3}{*}{$-/-$} & $\mathrm{G} / \mathrm{G}$ & $8(53.3 \%)$ & $7(46.7 \%)$ & 0.756 & 0.685 \\
\hline & $\mathrm{G} / \mathrm{T}$ & 12 (42.9\%) & $16(57.1 \%)$ & & \\
\hline & $\mathrm{T} / \mathrm{T}$ & $3(60 \%)$ & $2(40 \%)$ & & \\
\hline \multirow[t]{3}{*}{ F508del/- } & $\mathrm{G} / \mathrm{G}$ & $13(48.1 \%)$ & $14(51.9 \%)$ & 0.932 & 0.627 \\
\hline & $\mathrm{G} / \mathrm{T}$ & 17 (60.7\%) & 11 (39.3\%) & & \\
\hline & $\mathrm{T} / \mathrm{T}$ & $3(60 \%)$ & $2(40 \%)$ & & \\
\hline \multirow[t]{3}{*}{ F508del/F508del } & $\mathrm{G} / \mathrm{G}$ & $5(41.7 \%)$ & 7 (58.3\%) & 0.176 & 0.916 \\
\hline & $\mathrm{G} / \mathrm{T}$ & 1 (33.3\%) & $2(66.7 \%)$ & & \\
\hline & $\mathrm{T} / \mathrm{T}$ & $16(43.2 \%)$ & $21(56.8 \%)$ & & \\
\hline F508del & Diabetes & No & Yes & & \\
\hline \multirow[t]{3}{*}{$-/-$} & $\mathrm{G} / \mathrm{G}$ & $12(80 \%)$ & $3(20 \%)$ & 1.356 & 0.508 \\
\hline & $\mathrm{G} / \mathrm{T}$ & $21(77.8 \%)$ & $6(22.2 \%)$ & & \\
\hline & $\mathrm{T} / \mathrm{T}$ & 5 (100\%) & - & & \\
\hline \multirow[t]{3}{*}{ F508del/- } & $\mathrm{G} / \mathrm{G}$ & 19 (70.4\%) & $8(29.6 \%)$ & 2.858 & 0.24 \\
\hline & $\mathrm{G} / \mathrm{T}$ & 24 (88.9\%) & $3(11.1 \%)$ & & \\
\hline & $\mathrm{T} / \mathrm{T}$ & $4(80 \%)$ & $1(20 \%)$ & & \\
\hline \multirow[t]{3}{*}{ F508del/F508del } & $\mathrm{G} / \mathrm{G}$ & $8(66.7 \%)$ & 4 (33.3\%) & 2.042 & 0.36 \\
\hline & $\mathrm{G} / \mathrm{T}$ & $18(86.4 \%)$ & $3(13.6 \%)$ & & \\
\hline & $\mathrm{T} / \mathrm{T}$ & $29(78.4 \%)$ & $8(21.6 \%)$ & & \\
\hline F508del & meconium ileus & No & Yes & & \\
\hline \multirow[t]{3}{*}{$-/-$} & $\mathrm{G} / \mathrm{G}$ & 15 (100\%) & - & 2.286 & 0.319 \\
\hline & $\mathrm{G} / \mathrm{T}$ & $25(89.35)$ & $3(10.7 \%)$ & & \\
\hline & $\mathrm{T} / \mathrm{T}$ & $5(100 \%)$ & - & & \\
\hline \multirow[t]{3}{*}{ F508del/- } & $\mathrm{G} / \mathrm{G}$ & $22(81.5 \%)$ & $5(18.5 \%)$ & 0.073 & 0.964 \\
\hline & $\mathrm{G} / \mathrm{T}$ & $22(78.6 \%)$ & $6(21.4 \%)$ & & \\
\hline & $\mathrm{T} / \mathrm{T}$ & $4(80 \%)$ & $1(20 \%)$ & & \\
\hline \multirow[t]{3}{*}{ F508del/F508del } & $\mathrm{G} / \mathrm{G}$ & 10 (83.3\%) & $2(16.7 \%)$ & 3.335 & 0.189 \\
\hline & $\mathrm{G} / \mathrm{T}$ & 17 (77.3\%) & $5(22.75)$ & & \\
\hline & $\mathrm{T} / \mathrm{T}$ & 1 (33.3\%) & $2(66.7 \%)$ & & \\
\hline F508del & Age & $\leq 154$ months & $>154$ months & & \\
\hline \multirow[t]{3}{*}{$-/-$} & $\mathrm{G} / \mathrm{G}$ & $4(26.7 \%)$ & $11(73.3 \%)$ & 0.813 & 0.666 \\
\hline & $\mathrm{G} / \mathrm{T}$ & $6(21.4 \%)$ & $22(78.6 \%)$ & & \\
\hline & $\mathrm{T} / \mathrm{T}$ & $2(40 \%)$ & $3(60 \%)$ & & \\
\hline \multirow[t]{3}{*}{ F508del/- } & $\mathrm{G} / \mathrm{G}$ & $15(55.6 \%)$ & $12(44.45)$ & 2.641 & 0.267 \\
\hline & $\mathrm{G} / \mathrm{T}$ & $12(42.9 \%)$ & $16(57.1 \%)$ & & \\
\hline & $\mathrm{T} / \mathrm{T}$ & $4(80 \%)$ & $1(20 \%)$ & & \\
\hline \multirow[t]{3}{*}{ F508del/F508del } & $\mathrm{G} / \mathrm{G}$ & $9(75 \%)$ & $3(25 \%)$ & 1.37 & 0.504 \\
\hline & $\mathrm{G} / \mathrm{T}$ & 19 (86.4\%) & $3(13.6)$ & & \\
\hline & $\mathrm{T} / \mathrm{T}$ & $3(100 \%)$ & - & & \\
\hline
\end{tabular}

$(-)$ absence of F508del mutation. 
Table 4 Association IVS4G > T mutation in TCF7L2 gene after genotypic groupings, distributed by genotype for the mutation in the CFTR gene delF508 with clinical variables in cystic fibrosis patients followed at the Pediatric Clinic at UNICAMP with the distribution by mutations in the CFTR gene

\begin{tabular}{|c|c|c|c|c|c|}
\hline F508del & Sex & Male & Female & Chi-square & $\mathrm{p}$-value \\
\hline \multirow[t]{2}{*}{$-/-$} & $\mathrm{G} / \mathrm{G}$ & $8(53.3 \%)$ & 7 (46.7\%) & 0.257 & 0.613 \\
\hline & $\mathrm{G} / \mathrm{T}$ and $\mathrm{T} / \mathrm{T}$ & 15 (45.5\%) & $18(54.5 \%)$ & & \\
\hline \multirow[t]{2}{*}{ F508del/- } & $\mathrm{G} / \mathrm{G}$ & $13(48.1 \%)$ & $14(51.9 \%)$ & 0.931 & 0.335 \\
\hline & $\mathrm{G} / \mathrm{T}$ and $\mathrm{T} / \mathrm{T}$ & $20(60.6 \%)$ & $13(39.4 \%)$ & & \\
\hline \multirow[t]{2}{*}{ F508del/F508del } & $\mathrm{G} / \mathrm{G}$ & $5(41.7 \%)$ & 7 (58.3\%) & 0.018 & 0.893 \\
\hline & $\mathrm{G} / \mathrm{T}$ and $\mathrm{T} / \mathrm{T}$ & $11(44 \%)$ & $14(54 \%)$ & & \\
\hline F508del & Diabetes & No & Yes & & \\
\hline \multirow[t]{2}{*}{$-/-$} & $\mathrm{G} / \mathrm{G}$ & $12(80 \%)$ & $3(20 \%)$ & 0.01 & 0.919 \\
\hline & $\mathrm{G} / \mathrm{T}$ and $\mathrm{T} / \mathrm{T}$ & $26(81.3 \%)$ & $6(18.8 \%)$ & & \\
\hline \multirow[t]{2}{*}{ F508del/- } & $\mathrm{G} / \mathrm{G}$ & 19 (70.4\%) & $8(29.6 \%)$ & 2.652 & 0.103 \\
\hline & $\mathrm{G} / \mathrm{T}$ and $\mathrm{T} / \mathrm{T}$ & 28 (87.5\%) & $4(12.5 \%)$ & & \\
\hline \multirow[t]{2}{*}{ F508del/F508del } & $\mathrm{G} / \mathrm{G}$ & $8(66.7 \%)$ & $4(33.3 \%)$ & 1.437 & 0.231 \\
\hline & $\mathrm{G} / \mathrm{T}$ and $\mathrm{T} / \mathrm{T}$ & $21(84 \%)$ & $4(16 \%)$ & & \\
\hline F508del & Meconium ileus & No & Yes & & \\
\hline \multirow[t]{2}{*}{$-/-$} & $\mathrm{G} / \mathrm{G}$ & 15 (100\%) & - & 1.455 & 0.228 \\
\hline & $\mathrm{G} / \mathrm{T}$ and $\mathrm{T} / \mathrm{T}$ & 30 (90.9\%) & $3(9.1 \%)$ & & \\
\hline \multirow[t]{2}{*}{ F508del/- } & $\mathrm{G} / \mathrm{G}$ & $22(81.5 \%)$ & $5(18.5 \%)$ & 0.067 & 0.795 \\
\hline & $\mathrm{G} / \mathrm{T}$ and $\mathrm{T} / \mathrm{T}$ & $26(78.8 \%)$ & 7 (21.2\%) & & \\
\hline \multirow[t]{2}{*}{ F508del/F508del } & $\mathrm{G} / \mathrm{G}$ & 10 (83.3\%) & $2(16.7 \%)$ & 0.566 & 0.452 \\
\hline & $\mathrm{G} / \mathrm{T}$ and $\mathrm{T} / \mathrm{T}$ & 18 (72\%) & $7(28 \%)$ & & \\
\hline F508del & Age & $\leq 154$ months & $>154$ months & & \\
\hline \multirow[t]{2}{*}{$-/-$} & $\mathrm{G} / \mathrm{G}$ & $4(26.7 \%)$ & 11 (73.3\%) & 0.032 & 0.857 \\
\hline & $\mathrm{G} / \mathrm{T}$ and $\mathrm{T} / \mathrm{T}$ & $8(24.2 \%)$ & $25(75.8 \%)$ & & \\
\hline \multirow[t]{2}{*}{ F508del/- } & $\mathrm{G} / \mathrm{G}$ & 15 (55.6\%) & $12(44.4 \%)$ & 0.297 & 0.586 \\
\hline & $\mathrm{G} / \mathrm{T}$ and $\mathrm{T} / \mathrm{T}$ & $16(48.5 \%)$ & $17(51.5 \%)$ & & \\
\hline \multirow[t]{2}{*}{ F508del/F508del } & $\mathrm{G} / \mathrm{G}$ & $9(75 \%)$ & $3(25 \%)$ & 1.009 & 0.315 \\
\hline & $\mathrm{G} / \mathrm{T}$ and $\mathrm{T} / \mathrm{T}$ & 22 (88\%) & $3(12 \%)$ & & \\
\hline
\end{tabular}

$(-)$ absence of F508del mutation.

study, variation in TCF7L2 gene increased the risk of diabetes about threefold (HR 1.75 per allele, 95\% CI 1.32.4; $\mathrm{p}=0.0006$ ), and decreased the mean age at diabetes diagnosis by 7 years. In CF patients not treated with systemic glucocorticoids, the effect of TCF7L2 was even greater (HR 2.9 per allele, 95\% CI 1.7-4.9, $\mathrm{p}=0.00011$ ). A genetic variant conferring risk for type 2 diabetes in the general population is a modifier of risk for diabetes in CF.

Given these results, it became interesting to evaluate the other polymorphism, rs12255372 that is also related to a risk of diabetes among CF's patients. Our analysis, however, found no such correlation.

The absence of a relationship may be due to the sample size, but since this correlation is of great importance, it should have appeared even in a small sample. In any case, with an analysis of a larger number of patients it is possible that a relationship between the studied polymorphism and CF risk can still be evidenced.

\section{Patients and methods}

Patients were included in the study from the Pediatric Clinic at the Faculty of Medical Sciences of UNICAMP. The sample size calculation was performed by G-POWER program version 3.1 (using 0.05 alpha, 0.8 beta and $W$ size effect of 0.3 ). To have the statically power to all analyses using chi square test we need a population size of 143 patients. All patients were confirmed as having CF through two positive sodium and chloride sweat tests (value greater than $60 \mathrm{mmol} / \mathrm{L}$ ) and by analysis of differential membrane epithelium of the intestine by the dosage of active CFTR through the Ussing chamber. The identification of mutations in the CFTR gene was performed in the laboratory of 
Molecular Genetics, FCM/UNICAMP, which has the routine analysis tests for major mutations found in the population of Brazil, which are: F508del, G542X, R1162X, N1303K, G551D and N1303K. Of the patients initially included in the survey, only those without clinical data for statistical analysis and/or those who did not sign the informed consent were excluded.

The DNA was obtained by the extraction technique of phenol chloroform from $8 \mathrm{~mL}$ of venous blood. The concentration of DNA used for analysis was $50 \mathrm{ng} / \mathrm{mL}$. Genotyping was performed using the PCR technique associated with specific enzyme digestion.

The PCR reaction had a $25 \mu \mathrm{L}$ final volume with $100 \mathrm{ng}$ of DNA, $1 \mu \mathrm{M}$ of each primers, $200 \mathrm{mM}$ deoxynucleotide triphosphates, $1.3 \mathrm{mM} \mathrm{MgCl} 2,50 \mathrm{mM} \mathrm{KCl}, 10 \mathrm{mM}$ Tris $\mathrm{HCl}\left(\mathrm{pH} 8.4\right.$ at $\left.25^{\circ} \mathrm{C}\right), 0.1 \%$ Triton $\mathrm{X}-100$ and $0.35 \mathrm{U}$ Taq DNA polymerase. A pair of primers were designed and optimized to amplify the region of the mutation IVS4G > $\mathrm{T}$, resulting in amplification of $337 \mathrm{bp}\left(\mathrm{S}, 5^{\prime}\right.$ CTGGAAACTAAGGCGTGAGG-3' ${ }^{\prime}$, AS, $5^{\prime}$-TTGTTGAGCTTTACTGAGAT-3'). The procedure for the thermal cycling consisted of initial denaturation at $94^{\circ} \mathrm{C}$ for 7 min, subsequent denaturation at $94^{\circ} \mathrm{C}$ for $30^{\prime}$, annealing at $56^{\circ} \mathrm{C}$ for $45^{\prime}$, and extension at $72^{\circ} \mathrm{C}$ for $2 \mathrm{~min}$, repeated for 35 cycles, followed by a final extension at $72^{\circ} \mathrm{C}$ for $7 \mathrm{~min}$.

The product from the PCR had a size of $337 \mathrm{bp}$ and after digestion by the restriction enzyme Tsp509I, fragments of $143 \mathrm{bp}+99+95-\mathrm{G} / \mathrm{G}$ genotype, fragments of $126+17+99+95 \mathrm{bp}-\mathrm{T} / \mathrm{T}$ genotype and fragments of $143+126+99+95+17$ bp - genotype G/T were found.

Statistical analysis was performed using the Statistical Package for Social Sciences (SPSS) v.17.0 and Open Epi v.5.0 program. Data was compared by different tests according to data distribution. Initially, data was compared the chi square and Fisher exact test. For all the analyses we adopted the value of $\mathrm{p}=0.05$.

\section{Competing interests}

The authors declare that they have no competing interests.

\section{Authors' contributions}

DTF carried out the molecular genetic analysis, participated in the sequence alignment and drafted the manuscript. FALM participated in the design of the study and performed the statistical analysis. AFR and CSB conceived of the study, and participated in its design and coordination and helped to draft the manuscript. All authors read and approved the final manuscript.

\section{Acknowledgments}

BioEdit is acknowledged for re-reading the manuscript. Fapesp to financial support. And the http://www.laboratoriomultiusuario.com.br to possibility the study.

\footnotetext{
Author details

${ }^{1}$ Department of Medical Genetics, Faculty of Medical Sciences, University of Campinas (UNICAMP), Campinas, SP, Brazil. ${ }^{2}$ Department of Pediatrics, Faculty of Medical Sciences, University of Campinas (UNICAMP), Campinas, SP, Brazil. ${ }^{3}$ Universidade Estadual de Campinas (UNICAMP), Rua Tessália Vieira de Camargo, 126, Cidade Universitária, Campinas, SP 13081-970, Brazil.
}

Received: 4 May 2012 Accepted: 19 September 2012

Published: 10 October 2012

\section{References}

1. Tzetis M, Efthymiadou A, Doudounakis S, Kanavakis E: Qualitative and quantitative analysis of mRNA associated with four putative splicing mutations $(621+3 \mathrm{~A}->\mathrm{G}, 2751+2 \mathrm{~T}->\mathrm{A}, 296+1 \mathrm{G}->\mathrm{C}, 1717-9 \mathrm{~T}->\mathrm{C}-$ D565G) and one nonsense mutation (E822X) in the CFTR gene. Hum Genet 2001, 109(6):592-601.

2. Cystic Fibrosis Genetic Analysis Consortium - CFGAC. Disponível em: http:// www.genet.sickkids.on.ca/cftr. Accessed November 22, 2012.

3. Simmonds NJ, MacNeil SJ, Cullinan P, Hodson ME: Cystic fibrosis and survival to 40 years: a case-control study. Eur Respir J 2010, 36(6):1277-1283.

4. Moran A, Hardin D, Rodman D, Allen HF, Beall RJ, Borowitz D, Brunzell C, Campbell PW 3rd, Chesrown SE, Duchow C, Fink RJ, Fitzsimmons SC, Hamilton N, Hirsch I, Howenstine MS, Klein DJ, Madhun Z, Pencharz PB, Quittner AL, Robbins MK, Schindler T, Schissel K, Schwarzenberg SJ, Stallings VA, Zipf WB: Diagnosis, screening and management of cystic fibrosis related diabetes mellitus: a consensus conference report. Diabetes Res Clin Pract 1999, 45:61-73.

5. Mackie AD, Thornton SJ, Edenborough FP: Cystic fibrosis-related diabetes. Diabet Med 2003, 20:425-436.

6. Blackman SM, Hsu S, Ritter SE, Naughton KM, Wright FA, Drumm ML, Knowles MR, Cutting GR: A susceptibility gene for type 2 diabetes confers substantial risk for diabetes complicating cystic fibrosis. Diabetologia 2009, 52(9):1858-1865.

7. Milla CE, Warwick WJ, Moran A: Trends in pulmonary function in patients with cystic fibrosis correlate with the degree of glucose intolerance at baseline. Am J Respir Crit Care Med 2000, 162:891-895.

8. Mohan K, Israel KL, Miller H, Grainger R, Ledson MJ, Walshaw MJ: Long-term effect of insulin treatment in cystic fibrosis-related diabetes. Respiration 2008, 76:181-186.

9. Cowie CC, Rust KF, Byrd-Holt DD, Eberhardt MS, Flegal KM, Engelgau MM, Saydah SH, Williams DE, Geiss LS, Gregg EW: Prevalence of diabetes and impaired fasting glucose in adults in the U.S. population: National Health and Nutrition Examination Survey 1999-2002. Diabetes Care 2006, 29:1263-1268.

10. Grant SF, Thorleifsson G, Reynisdottir I, Benediktsson R, Manolescu A, Sainz J, Helgason A, Stefansson H, Emilsson V, Helgadottir A, Styrkarsdottir U, Magnusson KP, Walters GB, Palsdottir E, Jonsdottir T, Gudmundsdottir T, Gylfason A, Saemundsdottir J, Wilensky RL, Reilly MP, Rader DJ, Bagger Y, Christiansen C, Gudnason V, Sigurdsson G, Thorsteinsdottir U, Gulcher JR, Kong A, Stefansson K: Variant of transcription factor 7-like 2 (TCF7L2) gene confers risk of type 2 diabetes. Nat Genet 2006, 38:320-323.

11. Florez JC, Jablonski KA, Bayley N, Pollin TI, de Bakker PI, Shuldiner AR, Knowler WC, Nathan DM, Altshuler D: Diabetes Prevention Program Research Group. TCF7L2 polymorphisms and progression to diabetes in the Diabetes Prevention Program. N Engl J Med 2006, 355(3):241-250.

doi:10.1186/1756-0500-5-561

Cite this article as: Furgeri et al:: Association between the IVS4G > T mutation in the TCF7L2 gene and susceptibility to diabetes in cystic fibrosis patients. BMC Research Notes 2012 5:561.

\section{Submit your next manuscript to BioMed Central and take full advantage of:}

- Convenient online submission

- Thorough peer review

- No space constraints or color figure charges

- Immediate publication on acceptance

- Inclusion in PubMed, CAS, Scopus and Google Scholar

- Research which is freely available for redistribution 